\title{
Pengaruh Model Kooperatif Tipe Course Review Horay dalam Pembelajaran Tematik Terpadu di Sekolah Dasar
}

\author{
Indah Budianti ${ }^{1)}$, Reinita ${ }^{2)}$ \\ Pendidikan Guru Sekolah Dasar, Universitas Negeri Padang, Indonesia \\ E-mail: 1)indahbudianti21@gmail.com , 2) reinita reinita@yahoo.com
}

\begin{abstract}
Abstrak
Penelitian ini bertujuan untuk mengetahui pengaruh model Kooperatif Tipe Course Review Horay $(\mathrm{CRH})$ terhadap hasil belajar peserta didik dalam pembelajaran tematik terpadu di kelas V SDN Gugus V Kecamatan Sungai Tarab Kabupaten Tanah Datar. Penelitian ini merupakan penelitian kuantitatif dengan jenis penelitian eksperimen dan desain penelitian quasi eksperimen. Pengambilan data sampel dilakukan dengan teknik purposive sampling. Sampel penelitian ini berjumlah 40 orang dengan populasi sebanyak 74 orang. Instrumen yang digunakan dalam menggumpulkan data berupa tes objektif dengan bentuk pilihan ganda. Berdasarkan hasil analisis data menggunakan $t$-test, diperoleh $t_{\text {hitung }}>t_{\text {tabel }}$ yakni 2,84 $>$ 1,72 pada taraf signifikan 0,05 yang berarti $\mathrm{H}_{\mathrm{a}}$ diterima. Dengan demikian, terdapat pengaruh model Kooperatif Tipe Course Review Horay (CRH) dalam pembelajaran tematik terpadu di kelas V SDN Gugus V Kecamatan Sungai Tarab Kabupaten Tanah Datar.
\end{abstract}

Kata kunci: Course Review Horay, Hasil Belajar, Tematik Terpadu

\section{Abstract}

This study aims to determine the effect of the Course Review Horay $(\mathrm{CRH})$ Type cooperative model on student learning outcomes in integrated thematic learning in class V SDN Cluster $\mathrm{V}$, Sungai Tarab District, Tanah Datar Regency. This research is a quantitative research with experimental research type and a quasi experimental research design. The sample data was collected by using purposive sampling technique. The sample of this study amounted to 40 people with population 74 people. Instrument that used to collecting data in this research is objevtive test with multiple choice form. Based on the results of data analysis using t-test, obtained $t_{\text {count }}>t_{\text {table, }}$, is $2.84>1.72$ at a significant level of 0.05 , which means that $H_{a}$ is accepted. Thus, there is an effect of the Course Review Horay (CRH) Type Cooperative model in integrated thematic learning in class V SDN Cluster V, Sungai Tarab District, Tanah Datar Regency.

Keywords: Course Review Horay, Learning Outcomes, Integrated Thematic

\section{PENDAHULUAN}

Dalam perkembangan pendidikan saat ini pada tahun 2013 diberlakukan kurikulum baru yaitu kurikulum 2013, sesuai dengan Peraturan Menteri Pendidikan dan Kebudayaan Republik Indonesia No.81A Tahun 2013 tentang implementasi kurikulum menyatakan bahwa mulai tahun pelajaran 2013/2014 diberlakukan kurikulum 2013 secara bertahap. Kurikulum 2013 merupakan paradigma perubahan pembelajaran dari pembelajaran yang bersifat konvensional menjadi yang mengaktifkan peserta didik dengan adanya pembelajaran tematik.

Pembelajaran tematik terpadu merupakan sistem pendidikan yang memungkinkan peserta didik, baik secara individu maupun kelompok, aktif menggali dan menemukan konsep serta prinsip-prinsip dan keilmuan secara holistik, bermakna dan autentik (Rusman,2015). Hal ini berarti bahwa dalam pembelajaran tematik terpadu memungkinkan peserta didik memahami prinsip dan konsep dari hasil belajarnya sendiri, bukan sekedar pemberitahuan guru sehingga pengetahuan dan pembelajaran yang diperolehnya lebih bermakna. Peserta didik tidak lagi hanya mendengar guru berceramah dan mencatat dalam buku catatan mereka tetapi peserta didik dituntut untuk lebih aktif dan semangat dalam 
belajar karena pembelajaran tidak lagi berpusat kepada guru, tetapi pembelajaran berpusat kepada peserta didik. Untuk itu seorang guru harus bisa memilih model pembelajaran yang cocok dalam pembelajaran tematik terpadu yang membuat peserta didik aktif dalam belajar.

Salah satu model yang dianggap sesuai dengan pembelajaran tematik terpadu adalah model Kooperatif tipe Course Review Horay (CRH). Model pembelajaran kooperatif merupakan salah satu model pembelajaran yang melibatkan peserta didik untuk berpartisipasi aktif dalam kelompok kecil dengan saling membantu untuk mencapai tujuan pembelajaran. Didalam model kooperatif ini siswa memiliki dua tanggung jawab yaitu belajar untuk diri sendiri dan membantu sesama anggota kelompok untuk belajar (Reinita,2019).

Model kooperatif ini sangat beragam, salah satunya model kooperatif tipe Course Review Horay. Kurniasih \& Sani (2015:80) menyatakan bahwa model pembelajaran Course Review Horay $(\mathrm{CRH})$ merupakan model pembelajaran dengan pengujian pemahaman konsep siswa yang dituliskan pada kartu yang dilengkapi nomor dan bagi kelompok yang mendapatkan jawaban benar terlebih dahulu langsung berteriak "horay" atau menyanyikan yel-yel kelompoknya.

Huda (2013:230) menjelaskan bahwa model pembelajaran Course Review Horay $(\mathrm{CRH})$ membantu peserta didik untuk memahami konsep dengan baik melalui diskusi kelompok karena dengan model ini akan dilakukan pengujian pemahaman peserta didik pada materi pelajaran dan langsung dibahas sehingga peserta didik dapat langsung mengetahui jawabannya benar atau salah. Model ini melatih peserta didik menyelesaikan masalah, peserta didik yang paling terdahulu mendapatkan tanda benar berteriak hore atau yel-yel lainnya. Pembelajaran yang tidak monoton dengan diselingi sedikit hiburan sehingga tercipta suasana yang menyenangkan menjadikan peserta didik lebih aktif dan semangat dalam belajar.

Sejalan dengan pendapat Kurniasih \& Sani (2015:81) menjelaskan kelebihan model Course Review Horay (CRH) yaitu sebagai berikut : 1)Pembelajarannya menarik dan mendorong peserta didik untuk dapat terjun kedalamnya.2)Pembelajarannya tidak monoton karena diselingi sedikit hiburan sehingga suasana tidak menegangkan. 3)Peserta didik lebih semangat belajar karena suasana pembelajaran berlangsung menyenangkan. 5)Melatih kerjasama antar peserta didik di kelas.

Reinita (2017:2) juga menyatakan bahwa "The course review horay model can train students to be sensitive to current social problems, analyze existing social problems, take positions on the issue, and maintain attitudes with relevant and valid arguments so that students can participate in redefining the values social".

Penggunaan model kooperatif tipe Course Review Horay (CRH) ini dapat memberikan pengalaman belajar bekerjasama bekerjasama dalam kelompok, saling membantu dan tidak membedakan teman. Melalui kebersamaan peserta didik akan merasa nyaman, tidak ada rasa malu sehingga diharapkan peserta didik yang lemah tidak segansegan untuk menanyakan kesulitan yang dihadapinya. Saat peserta didik terbiasa menjawab soal dan dilakukan pembahasan secara langsung, siswa akan lebih memahami materi pembelajaran sehingga diharapkan nanti hasil belajarnya lebih baik.

Berdasarkan observasi yang telah peneliti lakukan di kelas V SDN Gugus V Kec. Sungai Tarab Kab.Tanah Datar, terlihat dalam proses pembelajaran tematik terpadu terlihat keterlibatan peserta didik dalam pembelajaran masih kurang. Dalam hal ini pembelalajaran masih berpusat pada guru, penyampaian materi hanya terpaku pada buku paket dan peserta didik hanya mendengarkan lalu diberi tugas untuk dikerjakan sendiri-sendiri.

Hal ini menyebabkan peserta didik masih terlihat pasif dan pembelajaran cenderung membosankan, serta kerja sama dan saling membantu satu sama lain tidak telihat karena peserta didik tidak dibiasakan menyelasaikan secara berkelompok atau berdiskusi. Hal ini dikerenakan pada proses pembelajaran guru tidak menggunakan model pembelajaran inovatif tetapi guru masih cenderung menggunakan model pembelajaran konvensional.

Menurut Ibrahim (2017:202) model pembelajaran konvensional adalah model pembelajaran tradisional dengan menggunakan metode ceramah, latihan soal dan pemberian tugas sehingga pembelajaran terpusat pada guru dan peserta didik hanya sebagai objek pembelajaran sehingga siswa peserta didik sulit untuk menyampaikan 
pendapatnya. Kurangnya inisiatif guru dalam membentuk pembelajaran yang menyenangkan sehingga peserta didik tidak semangat belajar berakibat pada rendahnya hasil belajar peserta didik kelas V SDN Gugus V Kecamatan Sungai Tarab Kabupaten Tanah Datar.

Berdasarkan pemaparan permasalahan diatas, maka perlu dilakukan sebuah penelitian sebagai upaya yang harus dilakukan guru yaitu dengan menggunakan model pembelajaran yang tepat sehingga menjadikan peserta didik lebih aktif dan semangat untuk belajar. Oleh karena itu peneliti melakukan penelitian eksperime, dengan judul "Pengaruh Model Kooperatif Tipe Course Review Horay Terhadap Hasil Belajar Peserta Didik Dalam Pembelajaran Tematik Terpadu di Kelas V SDN Gugus V Kecamatan Sungai Tarab Kabupaten Tanah Datar.

\section{METODE PENELITIAN}

Penelitian ini adalah penelitian kuantitatif jenis eksperimen. Sedangkan desain penelitian yang digunakan dalam penelitian ini adalah quasi eksperiment design. Sugiyono (2012:114) menyatakan penelitian eksperimen dengan jenis quasi eksperimen design adalah "suatu design penelitian yang memiliki kelompok kontrol tetapi tidak dapat berfungsi sepenuhnya untuk mengontrol variabel-variabel dari luar yang mempengaruhi pelaksanaan eksperimen". Dalam penelitian ini bentuk desain quasi eksperimen yang digunakan adalah nonequivalent control group design.

Penelitian kuantitatif eksperimen ini dilakukan untuk mengetahui pengaruh model kooperatif tipe Course Review Horay $(C R H)$ terhadap hasil belajar peserta didik dalam pembelajaran tematik terpadu di kelas V SDN gugus V Kecamatan Sungai Tarab Kabupaten Tanah Datar.

\section{Tabel 1. Rancangan Desain Penelitian}

\begin{tabular}{|c|c|c|c|c|}
\hline & 01 & $\mathrm{X}$ & $\mathrm{O} 2$ \\
\hline & & O3 & - & $\mathrm{O} 4$ \\
\hline & & \multicolumn{3}{|c|}{ Sumber : Sugiyono (2012:112) } \\
\hline \multicolumn{5}{|c|}{ Keterangan: } \\
\hline \multirow{6}{*}{$\begin{array}{l}\mathrm{O}_{1} \\
\mathrm{O}_{3} \\
\mathrm{O}_{2} \\
\mathrm{O}_{4} \\
\mathrm{X}\end{array}$} & \multirow{2}{*}{\multicolumn{4}{|c|}{$\begin{array}{l}=\text { Nilai pretest kelas eksperimen } \\
=\text { Nilai pretest kelas control }\end{array}$}} \\
\hline & & & & \\
\hline & \multirow{2}{*}{\multicolumn{4}{|c|}{$=$ Nilai posttest kelas eksperimen }} \\
\hline & \multirow{2}{*}{\multicolumn{4}{|c|}{$\begin{array}{l}=\text { Nilai posttest kelas control } \\
=\text { Perlakuan di kelas Eksperimen }\end{array}$}} \\
\hline & & & & \\
\hline & \multicolumn{4}{|c|}{ (Pembelajaran dengan model } \\
\hline
\end{tabular}

Keterangan :

Penelitian ini dilaksanakan di SDN 19 Pasir Lawas dan SDN 13 Pasir Lawas pada semester ganjil tahun ajaran 2020/2021. Populasi dalam penelitian ini terdiri dari seluruh peserta didik kelas V SDN Gugus V Kec. Sungai Tarab Kab.Tanah Datar yang berjumlah 74 orang. Sedangkan sampel dalam penelitian ini adalah peserta didik kelas V SDN 19 Pasir Lawas dan SDN 13 Pasir Lawas yang masing-masing kelas berjumlah 20 orang. Sampel dalam penelitian ini dipilih menggukan teknik purposive sampling. Purposive sampling merupakan teknik penentuan sampel dimana sampel ditentukan berdasarkan pertimbangan atau kriteria yang telah ditetapkan terlebih dahulu (Jakni,2016).

Adapun kriteria/dasar pertimbangan yang dibuat peneliti dalam penentuan sampel ini adalah sebagai berikut: 1)Peserta didik kelas V SDN 19 Pasir Lawas dan SDN 13 Pasir Lawas memiliki data yang berdistribusi normal dilihat dari hasil belajar. 2)Peserta didik kelas V SDN 19 Pasir Lawas dan SDN 13 Pasir Lawas memiliki varians yang homogen dilihat dari hasil belajar. 3)Peserta didik kelas V SDN 19 Pasir Lawas dan SDN 13 Pasir Lawas memiliki jumlah peserta didik sama banyak yaitu 20 orang. 4)Peserta didik SDN 19 Pasir Lawas dan SDN 13 Pasir Lawas beradi di gugus yang sama yaitu gugus $V \mathrm{Kec}$,Sungai Tarab. 5)Guru yang mengajar di kelas V SDN 19 Pasir Lawas dan SDN 13 Pasir Lawas sudah mengikuti profesi pendidik. 
Teknik pengumpulan data pada penelitian ini dilakukan dengan cara tes. Adapun instrument pada penelitian ini terdiri dari soal objektif dengan bentuk pilihan ganda dengan empat alternatif pilihan jawaban. Sebelum instrument digunakan dalam penelitian, terlebih dahulu dilakukan analisis instrument di antaranya: validitas, reablilitas, daya beda dan indeks kesukaran.

Untuk menentukan valid tidaknya suatu alat ukur dalam penelitian ini digunakan rumus Korelasi Biserial. Untuk menentukan reabilitas alat ukur dalam penelitian ini menggunakan K-R 20 (Kuder Richardson). Adapun teknik analisis data yang digunakan dalam penelitian ini adalah : uji normalitas, uji homogenitas dan uji t (t-test).

\section{HASIL DAN PEMBAHASAN}

\section{Deskripsi Data Pretest dan Posttest Kelas Eksperimen dan Kelas Kontrol}

Data hasil penelitian yang diperoleh merupakan data tes hasil belajar peserta didik pada tema 1 subtema 2 pembelajaran 3 dan 4 . Pada kelas eksperimen yang diberikan perlakuan menggunakan model Kooperatif Tipe Course Review Horay (CRH) dan kelas kontrol menggunakan pembelajaran konvensional. Sebelum diberi perlakuan diberikan pretest pada kedua kelas sampel terlebih dahulu. Hasil yang diperoleh pada pretest dan posttest dari kelas eksperimen dan kelas kontrol penelitian ini disajikan dalam tabel distribusi frekuensi berikut ini :

Tabel 2. Data Pretest dan Posttest Kelas Eksperimen dan Kelas Kontrol

\begin{tabular}{lcccc}
\hline & \multicolumn{2}{c}{ Kelas Eksperimen } & \multicolumn{2}{c}{$\begin{array}{c}\text { Kelas } \\
\text { Kontrol }\end{array}$} \\
\cline { 2 - 5 } & Hasil Pretest & Hasil Posttest & Hasil Pretest & Hasil Posttest \\
\hline $\mathbf{N}$ & 20 & 20 & 20 & 20 \\
\hline Nilai Min & 40 & 72 & 52 & 64 \\
\hline Nilai Max & 76 & 92 & 76 & 84 \\
\hline Rata-rata & 64,2 & 81,2 & 65,6 & 76,4 \\
\hline
\end{tabular}

Berdasarkan tabel 2 diatas dapat diketahui bahwa pada kelas eksperimen dan kelas kontrol sama-sama memiliki jumlah peserta didik sebanyak 20 orang. Nilai rata-rata pretest pada kelas eksperimen sebesar 64,2, dengan nilai tertinggi 76 dan nilai terendah 40 . Sedangkan rata-rata pretest pada kelas kontrol sebesar 65,6 dengan nilai tertinggi 76 dan nilai terendah 52. Dengan demikian rata-rata pretest kelas kontrol lebih tinggi dari pada ratarata pretest kelas eksperimen sebesar 1,4. Namun setelah dilakukan pembelajaran pada kelas eksperimen dengan menggunakan model pembelajaran Kooperatif Tipe Course Review Horay $(\mathrm{CRH})$ dan pada kelas kontrol dilakukan pembelajaran konvensional, diketahui bahwa nilai rata-rata posttest peserta didik kelas eksperimen sebesar 81,2 dengan nilai tertinggi 92 dan terendah 72, sedangkan rata-rata posttest kelas kontrol sebesar 76,4 dengan nilai tertinggi 84 dan nilai terendah 64 . Dengan demikian rata-rata posttest kelas eksperimen lebih tinggi dari pada rata-rata posstest kelas kontrol dengan selisih sebesar 4,8.

\section{Pengujian Prasayat Analisis dan Pengujian Hipotesis}

Uji normalitas dilakukan untuk mengetahui apakah data yang diperoleh berdistribusi normal atau tidak. Uji normalitas dalam penelitian ini menggunakan uji Liliefors dengan berbantu Microsoft Exel 2010 dengan taraf signifikansi 5\% atau $\alpha=0,05$. Hasil uji normalitas pretest pada kelas eksperimen dan kelas kontrol dalam penelitian ini disajikan pada tabel 3:

Berdasarkan tabel 3, diketahui hasil uji normalitas nilai pretest kelas eksperimen diperoleh $L_{\text {nitung }}$ sebesar 0,17 sedangkan $L_{\text {tabel }}$ pada taraf signifikasi 0,05 adalah 0,19 . Maka dapat disimpulkan bahwa $L_{\text {hitung }}<L_{\text {tabel }}(0,17<0,19)$ artinya kelas eksperimen berdistribusi normal. Sedangkan berdasarkan hasil uji normalitas nilai pretest kelas kontrol diperoleh $L_{\text {hitung }}$ sebesar 0,06 dan $L_{\text {tabel }}$ pada taraf signifikasi 0,05 adalah 0,19 . Dengan demikian dapat disimpulkan bahwa $L_{\text {hitung }}<L_{\text {tabel }}(0,06<0,19)$ artinya kelas kontrol berdistribusi normal. 
Tabel 3. Hasil Uji Normalitas Pretest Kelas Eksperimen dan Kelas Kontrol

\begin{tabular}{cccccc}
\hline No & Sampel & $\mathbf{N}$ & L Hitung & L tabel $\mathbf{\alpha} \mathbf{0 , 0 5}$ & Hasil Perhitungan \\
\hline $\mathbf{1}$ & $\begin{array}{c}\text { Kelas } \\
\text { Eksperimen }\end{array}$ & 20 & 0.17 & 0,19 & Normal \\
\hline $\mathbf{2}$ & $\begin{array}{c}\text { Kelas } \\
\text { Kontrol }\end{array}$ & 20 & 0.06 & 0,19 & Normal \\
\hline
\end{tabular}

Hasil uji normalitas posttest kelas eksperimen dan kelas kontrol dalam penelitian ini disajikan pada tabel berikut:

Tabel 4. Hasil Uji Normalitas Posttest Kelas Eksperimen dan Kelas Kontrol

\begin{tabular}{cccccc}
\hline No & Sampel & N & L Hitung & L tabel a 0,05 & $\begin{array}{c}\text { Hasil } \\
\text { Perhitungan }\end{array}$ \\
\hline $\mathbf{1}$ & $\begin{array}{c}\text { Kelas } \\
\text { Eksperimen }\end{array}$ & 20 & 0.05 & 0,19 & Normal \\
\hline $\mathbf{2}$ & $\begin{array}{c}\text { Kelas } \\
\text { Kontrol }\end{array}$ & 20 & 0.17 & 0,19 & Normal \\
\hline
\end{tabular}

Berdasarkan tabel 4, diketahui hasil uji normalitas nilai posttest kelas eksperimen

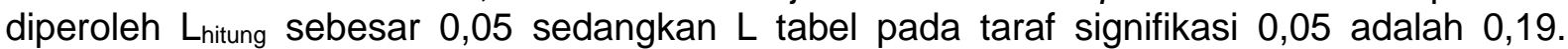
Maka dapat dismpulkan bahwa $L_{\text {hitung }}<L_{\text {tabel }}(0,05<0,19)$ artinya kelas eksperimen berdistribusi normal. Sedangkan hasil uji normalitas nilai posttest kelas kontrol diperoleh $L_{\text {hitung }}$ sebesar 0,17 sedangkan $L_{\text {tabel }}$ pada taraf signifikasi 017 adalah 0,19 . Maka dapat disimpulkan bahwa $L_{\text {hitung }}<L_{\text {tabel }}(0,17<0,19)$ artinya kelas kontrol berdistribusi normal.

\section{Uji Homogenitas}

Uji homogenitas dalam penelitian ini dilakukan untuk mengetahui apakah data untuk kelas eksperimen dan kelas kontrol memiliki varians yang homogen atau tidak. Uji homogenitas dalam penelitian ini dilakukan dengan menggunakan uji-F berbantu Microsoft Excel 2010 dengan taraf signifikasi $5 \%$ atau $\alpha=0,05$.

Hasil uji homogenitas pretest kelas eksperimen dan kelas kontrol dalam penelitian ini adalah sebagai berikut:

Tabel 5. Hasil Uji Homogenitas Pretest Kelas Eksperimen dan Kelas Kontrol

\begin{tabular}{|c|c|}
\hline $\mathrm{F}$ hitung & $\mathrm{F}$ tabel $\alpha 0,05$ \\
\hline 0,48 & 2,11 \\
\hline
\end{tabular}

Berdasarkan hasil uji homogenitas nilai pretest kelas eksperimen dan kelas kelas kontrol diperoleh Fhitung sebesar 0,48 sedangkan Ftabel pada taraf signifikasi 0,05 adalah 2,11. Maka dapat disimpulkan bahwa Fhitung < Ftabel $(0,48<2,11)$ artinya kelas eksperimen dan kelas kontrol bersifat homogen.

Hasil uji homogenitas posttest kelas eksperimen dan kelas kontrol dalam penelitian ini adalah sebagai berikut :

Tabel 6. Hasil Uji Homogenitas Posttest Kelas Eksperimen dan Kelas Kontrol

\begin{tabular}{cc}
\hline F hitung & $\mathbf{F}$ tabel $\boldsymbol{\alpha} \mathbf{0 , 0 5}$ \\
\hline $\mathbf{0 , 8 9}$ & 2,11 \\
\hline
\end{tabular}

Berdasarkan hasil uji homogenitas nilai posttest kelas eksperimen dan kelas kelas kontrol diperoleh $F_{\text {hitung }}$ sebesar 0,89 sedangkan $F_{\text {tabel }}$ pada taraf signifikasi 0,05 adalah 2,11. Maka dapat disimpulkan bahwa $F_{\text {hitung }}<F_{\text {tabel }}(0,89<2,11)$ artinya kelas eksperimen dan kelas kontrol bersifat homogen. 


\section{Uji Hipotesis}

Uji hipotesis dilakukan terhadap nilai posttest kelas eksperimen dan kelas kontrol. Berdasarkan uji prasyarat analisis data, diketahui bahwa data posttest untuk kedua kelompok berdistribusi normal dan memiliki varian yang homogen. Sehingga dapat dilakukan pengujian hipotesis dengan menggunakan uji t independent atau uji t sampel bebas dengan cara melakukann uji dua pihak. Hasil perhitungan nilai posttest dengan menggunakan uji t disajikan pada tabel berikut:

\section{Tabel 7. Hasil Uji T dua pihak Posttest Kelas Eksperimen dan Kelas Kontrol}

\begin{tabular}{cc}
\hline T hitung & $\mathbf{T}$ tabel $\boldsymbol{\alpha} \mathbf{0 , 0 5}$ \\
\hline $\mathbf{2 , 8 4}$ & 1,72 \\
\hline
\end{tabular}

Berdasarkan uji T yang dilakukan terhadap nilai posttest kelas eksperimen dan kelas kontrol, maka diperoleh thitung sebesar 2,84 dan tabel pada taraf signifikasi 0,05 adalah 1,72. Oleh karena $t_{\text {hitung }}>\mathrm{t}_{\text {tabel }}(2,1>1,72)$ maka $\mathrm{H}_{0}$ ditolak, dan $\mathrm{H}_{\mathrm{a}}$ diterima

\section{Pembahasan}

Penelitian ini dilakukan untuk mengetahui apakah ada pengaruh model Kooperatif Tipe Course Review Horay $(\mathrm{CRH})$ terhadap hasil belajar peserta didik dalam pembelajaran tematik terpadu dikelas V SDN Gugus V Kecamatan Sungai Tarab Kabupaten Tanah Datar.

Kelas eksperimen pada penelitian ini adalah kelas V SDN 19 Pasir Lawas yang diberi perlakuan dengan menggunakan model Kooperatif Tipe Course Review Horay (CRH), sedangkan kelas yang dijadikan kelas kontrol adalah kelas V SDN 13 Pasir Lawas yang melakukan pembelajaran konvensional.

Untuk mengetahui gambaran pengetahuan awal kedua kelas, maka terlebih dahulu dilakukan tes awal atau pretest. Untuk itu dilakukan uji prasayarat analisis yakni uji normalitas dan homogenitas data. Uji normalitas pada penelitian ini menggunakan uji Liliefors dengan ketentuan Lhitung<Ltabel maka data berdistribusi normal pada taraf signifikasi 0,05.

Berdasarkan uji Liliefors yang dilakukan terhadap nilai pretest kelas eksperimen diperoleh Lhitung sebesar 0,17, Ltabel pada taraf signifikasi 0,05 adalah 0,19, sehingga Lhitung < Ltabel artinya data pretest kelas eksperimen berdistribusi normal. Sedangkan pada kelas kontrol diperoleh Lhitung sebesar 0,06 dan Ltabel pada taraf signifikasi 0,05 adalah 0,19 . Sehingga Lhitung < Ltabel artinya kelas kontrol berdistribusi normal.

Uji normalitas juga dilakukan terhadap hasil nilai posttest kelas eksperimen dan kelas kontrol. Pada kelas eksperimen diperoleh Lhitung sebesar 0,05 dan Ltabel pada taraf signifikasi 0,05 adalah 0,19 , sehingga Lhitung < Ltabel artinya data posttest kelas eksperimen berdistribusi normal. Sedangkan pada kelas kontrol diperoleh Lhitung sebesar 0,17 dan Ltabel pada taraf signifikasi 017 adalah 0,19, sehingga Lhitung < Ltabel artinya data posttest kelas kontrol berdistribusi normal.

Selanjutnya dilakukan uji homogenitas dengan menggunakan uji Fisher dengan membandingkan nilai varians terbesar dan nilai varians terkecil. Berdasarkan uji fisher yang dilakukan terhadap hasil pretest kelas eksperimen dan kelas kontrol di peroleh $F$ hitung sebesar 0,48 dan F tabel pada taraf signifikansi 2,11. Dengan demikian dapat disimpulkan bahwa data pretest kedua kelas memiliki varians yang homogen. Kemudian uji Fisher juga dilakukan terhadap data posttest kedua kelas, berdasarkan hasil pengujian posttest kelas eksperimen dan kelas kontrol diperoleh $F$ hitung sebesar 0,89 dan $F$ tabel pada taraf signifikansi 2,11. Dengan demikian dapat disimpulkan bahwa data posttest kedua kelas memiliki varians yang homogen.

Berdasarkan analisis uji hipotesis dengan uji t diperoleh thitung sebesar 2,84 dan nilai ttabel pada taraf signifikasi 0,05 adalah 1,72, dimana thitung $>$ ttabel yaitu 2,84 >1,72. Dengan demikian HO ditolak, dan Ha diterima. Hasil penelitian ini memperlihatkan adanya pengaruh model pembelajaran Kooperatif Tipe Course Review Horay $(\mathrm{CRH})$ terhadap hasil 
belajar peserta didik dalam pembelajaran tematik terpadu di kelas V SDN Gugus $\mathrm{V}$ Kec.Sungai Tarab Kab.Tanah Datar. Dari hasil data posstest peserta didik kelas eksperimen dan kelas kontrol, diketahui bahwa hasil belajar peserta didik kedua kelompok penelitian ini menunjukkan adanya perbedaan yang signifikan, dengan rata-rata nilai posttest kelas eksperimen lebih tinggi sebesar 4,8 dibanding rata-rata kelas kontrol.

Berdasarkan hasil uji hipotesis yang telah dilakukan tentang pengaruh model pembelajaran Kooperatif Tipe Course Review Horay $(\mathrm{CRH})$ dapat disimpulkan bahwa terdapat pengaruh model Kooperatif Tipe Course Review Horay $(\mathrm{CRH})$ terhadap hasil belajar peserta didik dalam pembelajaran tematik terpadu di kelas V SDN Gugus V Kecamatan Sungai Tarab Kabupaten Tanah Datar.

\section{SIMPULAN}

Berdasarkan hasil penelitian quasi eksperimenT yang telah dilaksanakan pada pembelajaran tematik terpadu di kelas V SDN Gugus V Kec.Sungai Tarab Kab.Tanah Datar diperoleh nilai rata-rata kelas eksperimen 81,2 dan kelas kontrol 76,4. Hal ini menunjukkan bahwa kelas eksperimen yang melakukan pembelajaran dengan menggunakan model Kooperatif Tipe Course Review Horay $(\mathrm{CRH})$ memperoleh nilai rata-rata hasil belajar yang lebih tinggi dari pada kelas kontrol yang melakukan pembelajaran konvensional.

Dari hasil uji hipotesis dengan menggunakan uji t pada taraf signifikasi $5 \%$ atau $\alpha=$ 0,05 didapat $t_{\text {hitung }}$ sebesar 2,84 dan $t_{\text {tabel }}$ sebesar 1,72. Maka diperoleh $t_{\text {hitung }}>t_{\text {tabel }}(2,7>$ 1,72 ) sehingga $\mathrm{H}_{0}$ ditolak. Dengan demikian dapat disimpulkan bahwa terdapat pengaruh model Kooperatif Tipe Course Review Horay $(C R H)$ terhadap hasil belajar peserta didik dalam pembelajaran tematik terpadu di kelas V SDN Gugus V Kecamatan Sungai Tarab Kabupaten Tanah Datar.

\section{DAFTAR RUJUKAN}

Huda, Miftahul. (2013). Model-model Pengajaran dan Pembelajaran : Isu-isu Metodis dan Paradigmatis. Yogyakarta: Pustaka Belajar.

Ibrahim. 2017. Perpaduan Model Pembelajaran Aktif Konvensional (Ceramah) Dengan Cooperatif (Make - A Match) Untuk Meningkatkan Hasil Belajar Pendidikan Kewarganegaraan. Suara Guru .Jurnal IImu Pendidikan Sosial, sains, dan Humaniora.3(2):199-211.

Kurniasih, I \& Sani, B. 2015. Ragam Model Pembelajaran Untuk Peningkatan Profeisonalitas Guru. Jakarta: Kata Pena.

Reinita. (2017). Improved Process And Results of Civic Education (PKn) With Cooperative Model Course Review Horay In Elementary School. International Conferences on Educational.Social Sciences and Technology: 376-383.

Reinita \& Fitri, A. E. (2019). The Effect of Cooperative two Stay Two Stray Model on Civics Learning Outcomes of Primary School Student. Advances in Social Science, Education and Human Humanities Research. Vol.382:433-437.

Rusman. (2015). Pembelajaran Tematik Terpadu : Teori, Praktik, dan Penilaian. Jakarta : PT Raja Grafindo Persada.

Sugiyono. (2012). Metode Penelitian Pendidikan Pendekatan Kuantitatif, Kualitatif, dan $R$ \& D. Bandung: Alfabeta. 